HELMINTHOLOGIA, 53, 4: 336 - 353, 2016

\title{
Helminths of Milvago chimango temucoensis (Aves: Falconiformes) from Los Ríos Region, Chile: New Records for Neotropical Raptors
}

\author{
P. OYARZÚN-RUIZ1, ${ }^{1,}$ P. MUÑOZ-ALVARADO ${ }^{1 *}$, E. RAFFO ${ }^{3}$
}

\begin{abstract}
IInstituto de Patología Animal, Laboratorio de Parasitología Veterinaria, Facultad de Ciencias Veterinarias, Universidad Austral de Chile, Independencia 641, Valdivia, Chile, *E-mail: pamela.munoz@uach.cl; ²Programa de Magíster en Ciencias mención Salud Animal, Facultad de Ciencias Veterinarias, Universidad Austral de Chile, Independencia 641, Valdivia; ${ }^{3}$ Oficina de Protección de Recursos Naturales Renovables, Servicio Agrícola y Ganadero,Pedro Aguirre Cerda 2004,Region de los Ríos
\end{abstract}

Article info

Received April 27, 2016

Accepted September 28, 2016

\section{Summary}

The goal of the present survey was to improve the scarce knowledge regard the endoparasites of raptors in Chile and South America. Thus, necropsy was performed on 14 chimango caracara Milvago chimango temucoensis from Los Ríos Region, Chile. From all examined birds, $78.6 \%$ were positive to helminths. The species identified were Capillaria tenuissima, Pterothominx sp., Baruscapillaria falconis, Cosmocephalus obvelatus, Skrjabinoclava sp., Synhimantus (Dispharynx) nasuta, Synhimantus (D.) sp., Synhimantus (Synhimantus) sp., Paracuaria adunca, Procyrnea spinosa, Porrocaecum depressum, Contracaecum rudolphii sensu lato, Stephanoprora sp. and Polymorphus mutabilis. All species listed, with the exception of $C$. tenuissima, $P$. spinosa and $P$. depressum, are new records for the chimango caracara. Furthermore C. obvelatus, Skrjabinoclava sp., S. (D.) nasuta, S. (D.) sp., P. adunca, C. rudolphii s. I., Stephanoprora sp. and $P$. mutabilis all are new records for Neotropical raptors.

Keywords: chimango caracara; raptor; helminths; Chile

\section{Introduction}

Wild avifauna parasitism is ubiquitous, and the affected individuals suffer of multiple parasitic infections during their lives. However the study of the parasites that affect wildlife is generally scarce. One important fact is that the parasites presence always involves some sort of cost to the host (Wobeser, 2008).

Most of the endoparasites of the birds of prey have complex life cycles, with one or more intermediate hosts. The majority of the helminths use the bird's food as a pathway to infect them (Krone \& Cooper, 2002). When the parasitic infection involves a direct life cycle, or intermediate hosts are present (snails, arthropods or earthworms), the life cycles could be fulfilled and then the parasitism becomes endemic (Forbes, 2008).

Endoparasites are commonly found on adult free-living raptors, on which may cause minimal clinical disease unless the bird presents concomitant diseases, nutritional deficits (like adverse climate conditions and during the end of the nursing period) or trauma (Forbes, 2008). Parasites can be found associated with free-living and captivity-living raptors. The traditional opinion regarding parasites is that usually parasites do not cause severe damage to the host; however the pathogenicity levels are insufficiently studied, even when there are some reports describing the death of birds of prey due to parasitic infections (Krone \& Cooper, 2002).

In Chile, most of the parasitological surveys have been performed on veterinary relevant avian species; therefore the surveys dedicated to free-living birds are scarce and sporadically performed, being subjected to random or unintended findings. Wild birds most commonly studied correspond to kelp gull Larus dominicanus Lichtenstein 1823 (Charadriiformes, Laridae) and neotropic cormorant Phalacrocorax brasilianus Gmelin 1789 (Pelecaniformes, Phalacrocoracidae) (Hinojosa-Sáez \& González-Acuña, 2005). 
Table 1. Checklist of helminths isolated in Neotropical raptors of the genus Milvago; M. chimango and M. chimachima

\begin{tabular}{|c|c|c|c|}
\hline Host and helminths & Anatomical location & Country & References \\
\hline \multicolumn{4}{|l|}{ Milvago chimango } \\
\hline \multicolumn{4}{|l|}{ TREMATODA } \\
\hline Ophiosoma microcephalum & I & Argentina & Boero \& Led (1971) \\
\hline \multicolumn{4}{|l|}{ NEMATODA } \\
\hline Procyrnea spinosa & Pr; Gi & Chile & San Martín et al. (2006) \\
\hline Capillaria tenuissima & I & Chile & San Martín et al. (2006) \\
\hline Porrocaecum depressum & 1 & Chile & San Martín et al. (2006) \\
\hline Synhimantus milvagoi & St & Argentina & Boero \& Led (1971) \\
\hline \multicolumn{4}{|l|}{ Milvago chimachima } \\
\hline \multicolumn{4}{|l|}{ TREMATODA } \\
\hline Strigea falconis brasiliana & Sml & Argentina & Drago et al. (2014) \\
\hline Athesmia heterolecithodes & $\mathrm{BiDu}$ & Argentina; Brazil & Lunaschi \& Drago (2009); Travassos et al. (1969) \\
\hline Lubens lubens & $\mathrm{GaBl}$ & Brazil & Travassos et al. (1969) \\
\hline \multicolumn{4}{|l|}{ NEMATODA } \\
\hline Pelecitus sp. & TarTend & Brazil & Vicente et al. (1995); Pinto \& Noronha (2003) \\
\hline Skrjabinura spiralis & St; I & Brazil & Magalhães et al. (1994); Vicente et al. (1995) \\
\hline Contracaecum caballeroi & 1 & Brazil & Magalhães et al. (1994); Vicente et al. (1995) \\
\hline Synhimantus (Synhimantus) rectus & $\mathrm{St} ; \mathrm{Gi}$ & Brazil & Magalhães et al. (1994); Vicente et al. (1995) \\
\hline Procyrnea leptoptera & $\mathrm{Gi}$ & Brazil & Magalhães et al. (1994); Vicente et al. (1995) \\
\hline Thelazia sp. & Ey & Brazil & Vicente et al. (1995) \\
\hline Thelazia aquilina & Ey & Brazil & $\begin{array}{c}\text { Magalhães et al. (1994); Vicente et al. (1995); } \\
\text { Rodrigues (1996) }\end{array}$ \\
\hline
\end{tabular}

Abbreviations: E - esophagus; Cr - crop; St - stomach; Pr - proventriculus; Gi - gizzard; I - intestine; Sml - small intestine; GaBl - gall bladder;

BiDu - bile ducts; TarTend - tarsus's tendons; Ey - eyes

According to Raimilla et al. (2012), parasitic surveys on Chilean raptors are also scarce and focused mainly to ectoparasites, being available 7 reports for Falconiformes and only 1 for Strigiformes.

The genus Milvago Spix 1824 (Falconiformes, Falconidae) is composed by two Southamerican species: Milvago chimango Vieillot 1816 (Falconiformes, Falconidae) and Milvago chimachima Vieillot 1816 (Falconiformes, Falconidae). Chimango caracara M. chimango is a Neotropical raptor distribuited along Brasil, Paraguay, Argentina and Chile (Ferguson-Lees \& Christie, 2006). According to BirdLife International (2012) M. chimango is considered as a least concern species. In Chile there are two subspecies Milvago chimango chimango Vieillot 1816 (Falconiformes, Falconidae) in Central Chile and Milvago chimango temucoensis Sclater 1918 (Falconiformes, Falconidae) in Southern Chile (Ferguson-Lees \& Christie, 2006). In South America there are only two studies about the helminths of this raptor (Table 1), one of these was achieved on M. c. chimango from Nuuble province, Chile, as a result $95.2 \%$ of the birds were parasitized with three nematodes species: Procyrnea spinosa Chabaud 1958, Porrocaecum depressum Zeder 1800 and Capillaria tenuissima Rudolphi 1809 (San Martín et al. 2006).

The aim of this survey is to generate additional information re- garding the helminthological fauna of chimango caracara and the Neotropical birds of prey.

\section{Material and Methods}

Necropsy of 14 chimango caracaras M. c. temucoensis from 3 communes of the Los Ríos Region, Southern Chile was performed. The origin of the birds was: from Valdivia commune $(n=12)$, La Unión commune $(n=1)$ and Paillaco commune $(n=1)$. The studied area was represented by wetlands, native forests, grasslands, river estuaries and sea border.

The birds were obtained from animals that were sent to a wildlife rescue center (CEREFAS) that belongs to the local university "Universidad Austral de Chile". All the animals died due to the severity of their injuries or were euthanized for the same reasons. The biological material was obtained between spring 2012 and winter 2013. Once obtained, all the animals were tagged with the anamnesis information (origin, date of death, cause of death) and then the necropsy was performed. The digestive tract was examined from the cervical esophagus up to the cloaca, including crop, thoraxic esophagus, proventriculus, gizzard, gallbladder and intestine. The entire helminthological examen was performed at 
the Veterinary Parasitology Laboratory, of the Animal Pathology Institute at the Veterinary Sciences Faculty of the Universidad Austral de Chile.

The isolated parasites were preserved using $70 \%$ ethanol. The helminths were placed over a glass slide with Aman's lactophenol to achieve the diaphanization. The helminths were measured with the aid of a micrometric objective mounted on a light microscope, using 10x, 25x and 40x magnification optic objectives. All the measurements obtained were expressed in micrometers $(\mu \mathrm{m})$, unless otherwise stated, as the range followed by the mean in parenthesis. Several worms were mounted in glicerine and photographed with a CELESTRON Digital Microscope Imager $\mathrm{N}^{0}$ 44421 mounted on the light microscope. Helminths were mounted using glicerine. Parasitological parameters such as prevalence $(P)$, infection intensity $(I)$ and mean intensity $\left(I_{M}\right)$ were calculated as described by Bush et al. (1997). The infection intensity was expressed as a range in parenthesis, following the mean intensity. All isolated parasites were deposited in the helminthological collection of the Laboratory of Veterinary Parasitology of the Universidad Austral de Chile, Valdivia, Chile (1123Parasitol.UACh 1151Parasitol.UACh).

\section{Results}

From all the birds studied, the $78.6 \%(n=11)$ were positive to parasites. Helminths were found in all segments of the digestive tract, with the exception of the gallbladder. A total of 1,889 helminths were collected, from which $99.7 \%(n=1,883)$ corresponded to the Phylum Nematoda; $0.1 \%(n=2)$ to the Phylum Platyhelminthes, Class Trematoda; and $0.2 \%$ to the Phylum Acanthocephala $(n=4)$ (Table 2).

According to the anatomical location of the parasites, the organ that hosted the greatest burden of helminths was the whole intestine, with $95 \%$ of all the specimens isolated from it $(n=1,795)$.

Phylum Nematoda Rudolphi, 1808

Family Capillariidae Railliet, 1915

Genus Capillaria Zeder, 1800

Capillaria tenuissima (Rudolphi, 1809) Yamaguti, 1941 (Figs. 1 - 2; Table 3)

Description. (Based on 34 whole-mounted mature specimens) White filiform nematode. Anterior end is narrow and posterior end

Table 2. Helminths isolated in the digestive tract of chimango caracara Milvago chimango temucoensis $(n=14)$ from Los Ríos Region, Chile

\begin{tabular}{|c|c|c|c|c|}
\hline Helminth species & Anatomical location & Total & $P(\%)$ & $I_{M}$ \\
\hline \multicolumn{5}{|l|}{ NEMATODA } \\
\hline \multicolumn{5}{|l|}{ Capillaridae } \\
\hline Capillaria sp. & $\mathrm{E} ; \mathrm{Cr} ; \mathrm{I}$ & 17 & 35.70 & 3.40 \\
\hline Capillaria tenuissima & I & 1197 & 71.40 & 119.70 \\
\hline Pterothominx sp. & I & 104 & 35.70 & 20.80 \\
\hline Baruscapillaria falconis & I & 482 & 42.90 & 80.33 \\
\hline \multicolumn{5}{|l|}{ Habronematidae } \\
\hline Procyrnea spinosa & Glu; SbG; Gi; I & 8 & 28.60 & 2.00 \\
\hline \multicolumn{5}{|l|}{ Acuariidae } \\
\hline Cosmocephalus obvelatus & $\mathrm{Cr}$ & 2 & 7.10 & 2.00 \\
\hline Synhimantus (Dispharynx) sp. & $\mathrm{Cr}$ & 5 & 7.10 & 5.00 \\
\hline Synhimantus (Dispharynx) nasuta & Glu & 5 & 7.10 & 5.00 \\
\hline Synhimantus (Synhimantus) sp. & Glu & 4 & 14.30 & 2.00 \\
\hline Skrjabinoclava sp. & Glu & 2 & 7.10 & 2.00 \\
\hline Paracuaria adunca & Glu & 2 & 7.10 & 2.00 \\
\hline \multicolumn{5}{|l|}{ Ascarididae } \\
\hline Porrocaecum depressum & Glu; I & 20 & 35.70 & 4.00 \\
\hline \multicolumn{5}{|l|}{ Anisakidae } \\
\hline $\begin{array}{r}\text { Contracaecum rudolphii } \\
\text { sensu lato }\end{array}$ & Glu & 24 & 14.30 & 12.00 \\
\hline Undetermined Nematoda & Glu; SbG & 11 & 28.60 & 2.75 \\
\hline \multicolumn{5}{|l|}{$\begin{array}{l}\text { PLATYHELMINTHES } \\
\text { Echinostomatidae }\end{array}$} \\
\hline Stephanoprora sp. & I & 2 & 7.10 & 2.00 \\
\hline \multicolumn{5}{|l|}{$\begin{array}{l}\text { ACANTHOCEPHALA } \\
\text { Polymorphidae }\end{array}$} \\
\hline Polymorphus mutabilis & I & 4 & 7.10 & 4.00 \\
\hline
\end{tabular}



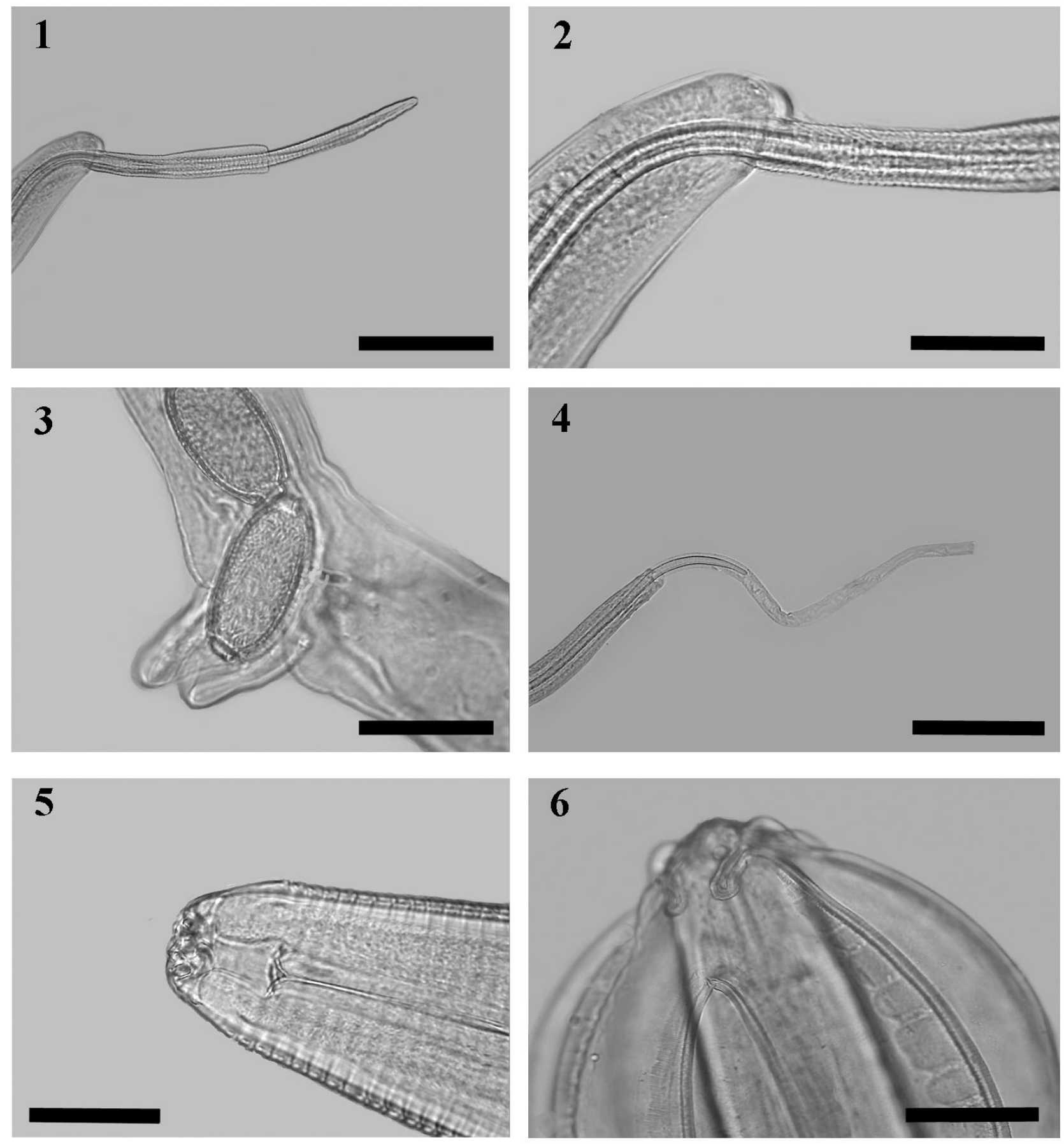

Figs. 1 - 6. Helminths isolated from chimango caracara Milvago chimango temucoensis.

Figs. 1 - 2. Capillaria tenuissima. 2. Posterior end of a male, it can be noted how the spicule is going out through the spicule sheath. Scale bar $=80 \mu \mathrm{m}$. 3. Little spines on the surface of the spicule sheath. Scale bar $=40 \mu \mathrm{m}$. Fig. 3. Vulvar appendix of Pterothominx sp.. Scale bar $=40 \mu \mathrm{m}$. Fig. 4. Posterior end of a male of Baruscapillaria falconis, note the length of the spicule sheath. Scale bar $=80 \mu \mathrm{m}$. Fig. 5. Anterior end of Procyrnea spinosa. Scale bar $=100 \mu \mathrm{m}$. Fig. 6. Anterior end of a female of Cosmocephalus obvelatus with its cephalic cordons covered with rectangular plates. Scale bar $=80 \mu \mathrm{m}$. 
stout. Males smaller than females, with a spicule covered with spicule sheath, which surface is covered with small spines. Nerve ring is located at the anterior portion of the esophagus. Stichosome organized in one column of stichocytes. Females, the vulva is located immediately caudal to the distal border of the esophagus. Vulvar appendix absent. Eggs with two plugs, and reticulated outer shell is present.

\section{Summary}

Site of infection: Intestine

Localities: Valdivia, Paillaco

Prevalence: 10 of 14 (71.4\%)

Mean intensity: $119.7(1-592)$

Comments: A total of 693 female and 504 male worms were isolated. The measures and morphology were coincident with Mettrick (1959) and Frantová (2002), similarly the characteristics indicated for spicule sheath, rough surface of eggs and the presence of two lobes at the posterior end of males. Some males had longer spicule sheath, this could be explained because this structure is retractile (Krone, unpublished data) and therefore this could explain these differences. The anatomical location in the birds was coincident with Krone (2000), who also isolated some specimens from the air sacs from the studied raptors, as well as Borgsteede et al. (2003), who isolated the nematodes from both intestine and intestinal ceca. Capillaria tenuissima has been recorded in various birds of the order Falconiformes and Strigiformes from Europe and North America (San Martín-Órdenes, 2011). In the case of Chile, it was isolated from the intestine of M. c. chimango from Ñuble (San Martín et al., 2006). The life cycle of $C$. tenuissima is unknown, in the case of earthworms being required as intermediate hosts, it is believed that rodents would act as paratenic hosts but a direct life cycle is suspected (Yabsley, 2008).

\section{Genus Pterothominx Freitas, 1959 \\ Pterothominx sp. (Fig. 3; Table 3)}

Description. (Based on 11 female whole-mounted gravid specimens) White filiform nematode. The esophagus is organized as a stichosoma, just like other capillarids. Female worms have a semi-circular and bilobulated vulvar appendix in contrast the other species of capillarids as the genus Capillaria and Baruscapillaria Moravec 1982 which lacks of it. The vulva is located caudal to the end of the esophagus near to the half of total length. Eggs with two plugs and outer shell finely punctate.

Table 3. Measurements of the nematodes of the family Capillariidae isolated from the chimango caracara in the present study

\begin{tabular}{|c|c|c|c|c|c|}
\hline & \multicolumn{2}{|c|}{ Capillaria tenuissima } & \multirow{2}{*}{$\begin{array}{c}\text { Pterothominx sp. } \\
\quad+(\mathrm{n}=11)\end{array}$} & \multicolumn{2}{|c|}{ Baruscapillaria falconis } \\
\hline & $q(n=10)$ & $\hat{\jmath}(\mathrm{n}=24)$ & & $q(n=6)$ & $\hat{\sigma}(n=6)$ \\
\hline $\mathrm{BL}$ & $8.35-14.06 \mathrm{~mm}$ & $6.19-11.87 \mathrm{~mm}$ & $11.25-14.67 \mathrm{~mm}$ & $8.47-12.41 \mathrm{~mm}$ & $9.14-12.61 \mathrm{~mm}$ \\
\hline ETL & $3.09-5.47 \mathrm{~mm}$ & $3.06-5.54 \mathrm{~mm}$ & $3.99-5.67 \mathrm{~mm}$ & $3.57-4.95 \mathrm{~mm}$ & $3.76-5.18 \mathrm{~mm}$ \\
\hline EW & 12.0 & $9.0-12.0$ & $12.0-15.0$ & $9.0-12.0$ & $9.0-12.0$ \\
\hline DAN & $186.0-336.0$ & $240.0-414.0$ & $252.0-444.0$ & $307.5-510.0$ & $267.0-390.0$ \\
\hline DAV & $3.32-5.79 \mathrm{~mm}$ & - & $4.42-6.07 \mathrm{~mm}$ & $3.96-5.34 \mathrm{~mm}$ & - \\
\hline DEV & $6.0-30.0$ & - & $12.0-54.0$ & $45.0-90.0$ & - \\
\hline DPCL & $3.0-18.0$ & $12.0-33.0$ & $12.0-27.0$ & $12.0-18.0$ & $24.0-27.0$ \\
\hline BWNR & $18.0-24.0$ & $18.0-30.0$ & $12.0-39.0$ & $15.0-22.5$ & $18.0-21.0$ \\
\hline BWEI & $45.0-67.0$ & $37.5-67.5$ & $60.0-82.5$ & $37.5-52.5$ & $39.0-48.0$ \\
\hline BWV & $45.0-67.1$ & - & $60.0-82.5$ & $37.5-52.5$ & - \\
\hline BWCL & $30.0-36.0$ & $24.0-54.0$ & $36.0-45.0$ & $30.0-33.0$ & $24.0-27.0$ \\
\hline $\mathrm{EL}$ & $57.0-69.0$ & - & $66.0-72.0$ & $51.0-60.0$ & - \\
\hline EW & $30.0-33.0$ & - & $33.0-39.0$ & $27.0-30.0$ & - \\
\hline SL & - & $0.84-1.30 \mathrm{~mm}$ & - & - & $0.33-1.13 \mathrm{~mm}$ \\
\hline SW & - & $6.0-18.0$ & - & - & $6.0-9.0$ \\
\hline SSL & - & $69.0-258.0$ & - & - & $1.35-4.59 \mathrm{~mm}$ \\
\hline SSW & - & $12.0-27.0$ & - & - & $12.0-15.0$ \\
\hline LW & - & $6.0-18.0$ & - & - & 9.0 \\
\hline RSSL/BL & - & $0.011-0.021$ & - & - & $0.142-0.357$ \\
\hline
\end{tabular}

Abbreviations: BL - Body length; ETL - Esophagus total length; EW - Stichocyte width; DAN - Distance between anterior end-nerve ring; DAV - Distance between anterior end-vulva; DEV - Distance between distal end esophagus-vulva; DPCL - Distance between posterior end-cloacal aperture; BWNR - Body width at nerve ring; BWEI - Body width at esophagus-intestinal union; BWV - Body width at vulva; BWCL - Body width at cloacal aperture; EL - Eggs length; EW - Eggs width; SL - Spicule length; SW - Spicule width; SSL - Spicule sheath length; SSW - Spicule sheath width; LW - Lobe width; RSSL/BL - Ratio spicule sheath length/body length 
Summary

Site of infection: Intestine

Localities: Valdivia, Paillaco

Prevalence: 5 of $14(35.7 \%)$

Mean intensity: $20.8(1-78)$

Comments: A total of 104 female worms were isolated. No males were detected in the studied birds. Both, measures and morphology of females (shape of vulvar appendix and surface of outer shell of eggs) and anatomical location in the hosts were coincident with the data regard Pterothominx caudinflata (Molin 1858) Okulewicz 1993 (Kellog \& Prestwood, 1968; Ruff \& Norton, 1997). However the characteristics of the posterior end of males are needed to achieve the species identification. In addition, the anatomical location was coincident with Borgsteede et al. (2003), who isolated this parasite from birds of prey.

Worldwide, $P$. caudinflata has been isolated from the small intestine of Columbiformes, Strigiformes, Passeriformes and Galliformes from Europe and North America (Yabsley, 2008). There is one record for this helminth for Falco tinnunculus Linnaeus 1758 (Falconiformes, Falconidae) from The Netherlands (Borgsteede et al., 2003). In Chile P. caudinflata has been diagnosed in Columba livia Gmelin 1789 (Columbiformes, Columbidae) from Valdivia (Pazmiño, 2007). This nematode has an indirect life cycle with earthworms as intermediate host (Yabsley, 2008). Thus, we propose the possibility of transmission between this two species, through the intake of infected earthworms, because pigeons and chimango caracaras share roosts sites and preys (earthworms), facilitating the infection.

Genus Baruscapillaria Moravec, 1982

Baruscapillaria falconis (Goeze, 1782) Barus \& Sergejeva, 1990 (Fig. 4; Table 3)

Description. (Based on 12 whole-mounted mature specimens) White filiform nematode. Males of this species have a very long spicule sheath, of almost one third of the total length, which lack of spines on its surface. Also the surface of both the spicule and the sheath spicule, are transversally striated. The females have a little prominence erecting laterally at the vulvar zone. Inner shell of the eggs bents to form a collar, with its characteristic vertical serration and reticulated outer shell.

\section{Summary}

Site of infection: Intestine

Localities: Valdivia, Paillaco

Prevalence: 6 of $14(42.9 \%)$

Mean intensity: $80.3(1-277)$

Comments: A total of 118 female and 364 male worms were isolat- ed. Size and morphology were coincident with Kellog \& Prestwood (1968), Read (1949) and Krone \& Cooper (1999). Some measures were similar to Baruscapillaria obsignata (Madsen 1945) Moravec 1982 described by Mettrick (1959), Kajerová \& Barus (2005) and Ávila et al. (2011). The differentiation with $B$. falconis comes from characteristics for both males and females. Male has a striated spicule along its entire length and eggs from females have a bented inner shell forming a collar (Read, 1949). All these characteristics are absent in $B$. obsignata.

In Chile, the nematode $B$. falconis has been reported in Falco sparverius cinnamominus Swainson 1838 (Falconiformes, Falconidae) (González-Acuña et al., 2011). This species has also been isolated from the small intestine of Strigiformes and Accipitriformes from North America and Europe (Read, 1949; Borgsteede et al., 2003). Another species of Baruscapillaria recorded in Chile is $B$. obsignata, which has been diagnosed in the intestine of Galliformes and Columbiformes (San Martín-Órdenes, 2011). The latter has a direct life cycle (Yabsley, 2008), thus it is probable that the life cycle of $B$. falconis is direct as $B$. obsignata.

\section{Family Habronematidae Chitwood \& Wehr, 1932 \\ Genus Procyrnea Chabaud, 1958}

Procyrnea spinosa (Chabaud, 1958) Gendre, 1922 (Fig. 5; Table 4)

Description. (Based on 8 whole-mounted mature specimens) Anterior end has pseudolabias and a short and wide vestibule. Also has oval deirids. The entire body has transversal striations. Vulva is located slightly caudal to the half of the total length of the body. The posterior end of males is coiled on itself, also has two spicules; the left spicule is longer that the right one, both are thin. In order to the spicules to go out from the body, they use a structure called gubernaculum, which is irregularly-shaped. Males also have four pair of pre-cloacal papillae, two pair of post-cloacal papillae and one pair of sessile papillae. The posterior end of females is conic.

\section{Summary}

Site of infection: Gizzard, under the linning of gizzard, intestine Localities: Valdivia, Paillaco

Prevalence: 4 of $14(28.6 \%)$

Mean intensity: $2.0(1-3)$

Comments: Five female and 3 male worms were isolated. The presence of tooth in pseudolabia, spine-like process at the left spicule, gubernaculum and short lateral alae limited to the first third are coincident with the description of Mawson (1968). According to this author, the morphology between this species and Procyrnea falco Mawson 1968, from Australia, are very similar, however for the former, the left spicule has two spine-like processes on its distal border. Procyrnea spinosa has been isolated in F. tinnunculus 
Table 4. Measurements of the nematodes of the families Habronematidae, Ascarididae and Anisakidae isolated from the chimango caracara in the present study

\begin{tabular}{|c|c|c|c|c|c|}
\hline & \multicolumn{2}{|c|}{ Procyrnea spinosa } & \multicolumn{2}{|c|}{ Porrocaecum depressum } & \multirow{2}{*}{$\begin{array}{c}\text { Contracaecum } \\
\text { rudolphii s. lato } \\
\hat{\sigma}(n=2)\end{array}$} \\
\hline & $q(n=5)$ & $\widehat{\partial}(n=3)$ & 오 $(\mathrm{n}=2)$ & $\hat{\partial}(n=1)$ & \\
\hline $\mathrm{BL}$ & $10.01-15.26 \mathrm{~mm}$ & $8.76-10.33 \mathrm{~mm}$ & $95.00-106.00 \mathrm{~mm}$ & $73.00 \mathrm{~mm}$ & $12.58-14.94 \mathrm{~mm}$ \\
\hline ETL & $3.81-4.94 \mathrm{~mm}$ & $3.55-3.90 \mathrm{~mm}$ & $3.66-4.90 \mathrm{~mm}$ & $3.63 \mathrm{~mm}$ & $1.86-2.27 \mathrm{~mm}$ \\
\hline ICL & - & - & $2.19-3.67 \mathrm{~mm}$ & $3.05 \mathrm{~mm}$ & $1.25-1.47 \mathrm{~mm}$ \\
\hline IL & - & - & $127.5-180.0$ & 113.7 & $38.6-51.4$ \\
\hline VEL & - & - & $0.76-1.05 \mathrm{~mm}$ & 570.0 & $634.5-759.9$ \\
\hline VL & $37.5-45.0$ & 30.0 & - & - & - \\
\hline VW & 12.0 & $6.0-9.0$ & - & - & - \\
\hline GEL & $3.36-4.41 \mathrm{~mm}$ & $3.06-3.45 \mathrm{~mm}$ & - & - & - \\
\hline GEW & $127.5-180.0$ & $150.0-180.0$ & - & - & - \\
\hline MEL & $0.45-0.60 \mathrm{~mm}$ & $0.45-0.49 \mathrm{~mm}$ & - & - & - \\
\hline MEW & $30.0-48.0$ & $27.0-36.0$ & - & - & - \\
\hline DAN & $315.0-354.0$ & $276.0-315.0$ & - & - & - \\
\hline DAD & $162.0-180.0$ & $147.0-204.0$ & - & 255.0 & - \\
\hline DAE & $414.0-471.0$ & $360.0-408.0$ & - & - & 172.5 \\
\hline DAV & $8.23-8.48 \mathrm{~mm}$ & - & $26.00-31.00 \mathrm{~mm}$ & - & - \\
\hline DPCL & $127.5-157.5$ & $172.5-210.0$ & $645.0-720.0$ & 282.0 & $180.0-195.0$ \\
\hline DPPH & $24.0-27.0$ & - & $75.0-82.5$ & - & - \\
\hline BWNR & $150.0-157.0$ & $127.5-157.5$ & - & - & - \\
\hline BWD & $105.0-135.0$ & $112.5-135.0$ & - & - & - \\
\hline BWEI & $382.5-405.0$ & $270.0-360.0$ & - & - & - \\
\hline BWEVE & - & - & $1.29-1.51 \mathrm{~mm}$ & $1.17 \mathrm{~mm}$ & $337.5-450.0$ \\
\hline BWV & $435.0-465.0$ & - & $1.88-1.94 \mathrm{~mm}$ & - & - \\
\hline BWCL & $165.0-180.0$ & $122.3-127.2$ & $592.5-780.0$ & 322.5 & 165.0 \\
\hline EL & $36.0-42.0$ & - & $99.8-107.9$ & - & - \\
\hline EW & $18.0-24.0$ & - & $67.0-84.7$ & - & - \\
\hline LSL & - & $1.54-1.59 \mathrm{~mm}$ & - & $1.24 \mathrm{~mm}$ & $5.82-7.09 \mathrm{~mm}$ \\
\hline RSL & - & $0.36-0.39 \mathrm{~mm}$ & - & $1.15 \mathrm{~mm}$ & $5.58-6.33 \mathrm{~mm}$ \\
\hline $\mathrm{ML}$ & - & - & 15.0 & 15.0 & - \\
\hline RMEL/GEL & $0.133-0.136$ & $0.142-0.147$ & - & - & - \\
\hline RRSL/LSL & - & $0.233-0.245$ & - & 0.927 & $0.892-0.958$ \\
\hline
\end{tabular}

Abbreviations: BL - Body length; ETL - Esophagus total length; ICL - Intestinal cecum length; IL - Interlabia length; VEL - Ventriculus length; VL Vestibule length; VW - Vestibule width; GEL - Glandular esophagus length; GEW - Glandular esophagus width; MEL - Muscular esophagus length; MEW - Muscular esophagus width; DAN - Distance between anterior end-nerve ring; DAD - Distance between anterio end-deirid; DAE - Distance between anterior end-excretory pore; DAV - Distance between anterior end-vulva; DPCL - Distance between posterior end-cloacal aperture; DPPH Distance between posterior end-phasmid; BWNR - Body width at nerve ring; BWD - Body width at deirid; BWEI - Body width at esophagus-intestinal union; BWEVE - Body width at esophagus-ventriculus union; BWV - Body width at vulva; BWCL - Body width at cloacal aperture; EL - Eggs length; EW - Eggs width; LSL - Left spicule length; RSL - Right spicule length; ML - Mucron length; RMEL/GEL - Ratio muscular esophagus length/glandular esophagus length; RRSL/LSL - Ratio right spicule length/left spicule length

from Tunisia. Another species isolated from the proventriculus and gizzard of birds of prey are Procyrnea mansioni (Seurat 1914) Chabaud 1975, Procyrnea leptoptera (Rudolphi 1819) Chabaud 1975 and Procyrnea dollfusi Mawson 1968 from Brazil and Australia. (Mawson, 1968; Magalhães et al., 1994; Zhang \& Beveridge, 2007). In the present study it was also isolated from the intestine, which could be a post mortem migration of the nematodes. According to Mawson (1968) P. falco is very close to $P$. spinosa, however until a detailed comparative study, is preferable to keep them as separate species. The life cycle is indirect, using muscoid flies and houseflies as intermediate hosts (Su \& Fei, 2004).
In Chile it was detected in the study by San Martín et al. (2006) in chimango caracara. Also, Procyrnea sp. Chabaud 1958 has been isolated in F. s. cinnamominus from Chile and Brazil (Magalhães et al., 1994; González-Acuña et al., 2011) and Elanoides forficatus Linnaeus 1758 (Accipitriformes, Accipitridae) from North America (Coulson et al., 2010).

Family Acuariidae Seurat 1913

Genus Cosmocephalus Molin, 1858

Cosmocephalus obvelatus (Creplin, 1825) Seurat, 1919 (Fig. 6; Table 5) 
Description. (Based on 1 whole-mounted mature female specimen) Medium-sized white nematode. This parasite has two pairs of cordons at the anterior end. These are non-ondulated and each cordon has cuticular plates on its surface along the entire cordon. The posterior end has a rectangular structure on its tip, with three rounded projections. Esophagus is divided in an anterior muscular and a posterior glandular segment, being the latter of greater length. It has two bicuspid deirids, which rest on a bicuspid circular base at the anterior end. The excretory pore is slightly caudal to deirid. It is also remarkable the presence of two lateral alae, extending from posterior level of deirids.

\section{Summary}

Site of infection: Crop

Locality: Valdivia

Prevalence: 1 of $14(7.1 \%)$

Mean intensity: 2.0 (2)

Comments: One adult female and 1 larval specimen were isolated. The adult female was found penetrating the mucosa of the crop with notorious swelling associated to the area. The larvae corresponded to a L4 stage. All the morphologic characteristics, for both adult and larva, were coincident with the detailed description of Wong \& Anderson (1982a) and Mutafchiev et al. (2010), however the eggs were smaller in the present study. The adult female nematode was smaller regarding the description of the above mentioned authors, however was coincident with the description of Azuma et al. (1988).

Cosmocephalus obvelatus is a nematode of fish-eating birds, using fishes as intermediate hosts (Wong \& Anderson, 1982a). The infective stage, $L 3$, has been isolated from several South American fishes as Atheriniformes from Argentina and Perciformes from Malvinas (Brickle \& MacKenzie, 2007; Carballo et al., 2011). As a representative of the family Acuariidae, Cosmocephalus sp. Molin 1858 was identified in Spheniscus humboldti Meyen 1834 (Sphenisciformes, Spheniscidae) from Valparaiso Region, Chile (Mann, 1992), while the species C. obvelatus was isolated from the esophagus of Eudyptes chrysocome Forster 1781 (Sphenisciformes, Spheniscidae) from Chile, and from the same organ in Spheniscus magellanicus Forster 1781 (Sphenisciformes, Spheniscidae) and L. dominicanus from Argentina (Azuma et al., 1988; Díaz et al., 2001; 2010; 2011). To our knowledge, there is no previous data regarding this nematode in a bird of prey in South America.

\section{Genus Paracuaria Krishna Rao, 1951}

Paracuaria adunca Creplin, 1846 (Table 5)

Description. (Based on 2 whole-mounted mature male specimens) Thin nematode, with two pseudolabias and one pair of interlabias, and two cordon-like structures at the anterior end. Also, has one pair of tricuspid deirids, located caudal to the nerve ring at the anterior end. The posterior end has two spicules with different length. The left spicule has a small spine-like projection at the distal end in cranial direction. Also, the posterior end has 4 pair of pre-cloacal papillae and 6 pair of post-cloacal papillae, which are all pedunculated with the exception of one pair of sessile papillae.

\section{Summary}

Site of infection: Gastric lumen

Locality: Valdivia

Prevalence: 1 of $14(7.1 \%)$

Mean intensity: $2.0(2)$

Comments: Only 2 male nematodes were isolated. The morphological characteristics, including the number of pre-cloacal and post-cloacal papillae, are coincident with the description of Wong \& Anderson (1982b) and Díaz et al. (2004). The measurements of the specimens in the present study turned out larger that the description by the authors above but are coincident with the description of Rao (1951), who named the parasite as P. macdonaldi (Rao), which is actually considered a synonymous of $P$. adunca. This species of nematode has been isolated from the proventriculus and under the linning of the gizzard of Charadriiformes and Gaviiformes (Rao, 1951; Anderson \& Wong, 1982; Díaz et al., 2004; 2011). Under the light microscope, near the middle of the total length of the left spicule, a constriction is present, which is coincident with the division of the spicule to form a tube, as was described by Díaz et al. (2004).

The genus Paracuaria has two species, one of them; $P$. adunca has been isolated from fish-eating birds (Laridae, Gaviidae, Podicipedidae, Diomedeidae, Anatidae, Alcidae, Pelecanidae and Rynchopidae) in many countries of the world (Wong \& Anderson, 1982b). According to an experimental study by Anderson \& Wong (1982), this parasite infects fishes effectively, which would then act as intermediate hosts. Therefore, the piscivorous diet of the chimango caracara would allow acquiring the nematode. In South America it has been isolated in $L$. dominicanus from Argentina (Díaz et al., 2004; 2011). To our knowledge the specimens of the present study corresponds to the first record in a raptor. Because of the absence of gravid females it is difficult to establish that chimango caracara is a suitable definitive host, therefore additional studies are recquired.

\section{Genus Synhimantus Railliet, Henry \& Sisoff, 1912 Synhimantus (Dispharynx) nasuta (Rudolphi, 1819) Chabaud, 1975 (Fig. 7; Table 5)}

Description. (Based on 5 whole-mounted mature male specimens) Anterior end has two pairs of recurrent non-anastomosed cephalic cordons, which continue along the axis of body and at muscular esophagus level became recurrent with non-anastomosed branches. The descending cephalic cordons have rectangular 

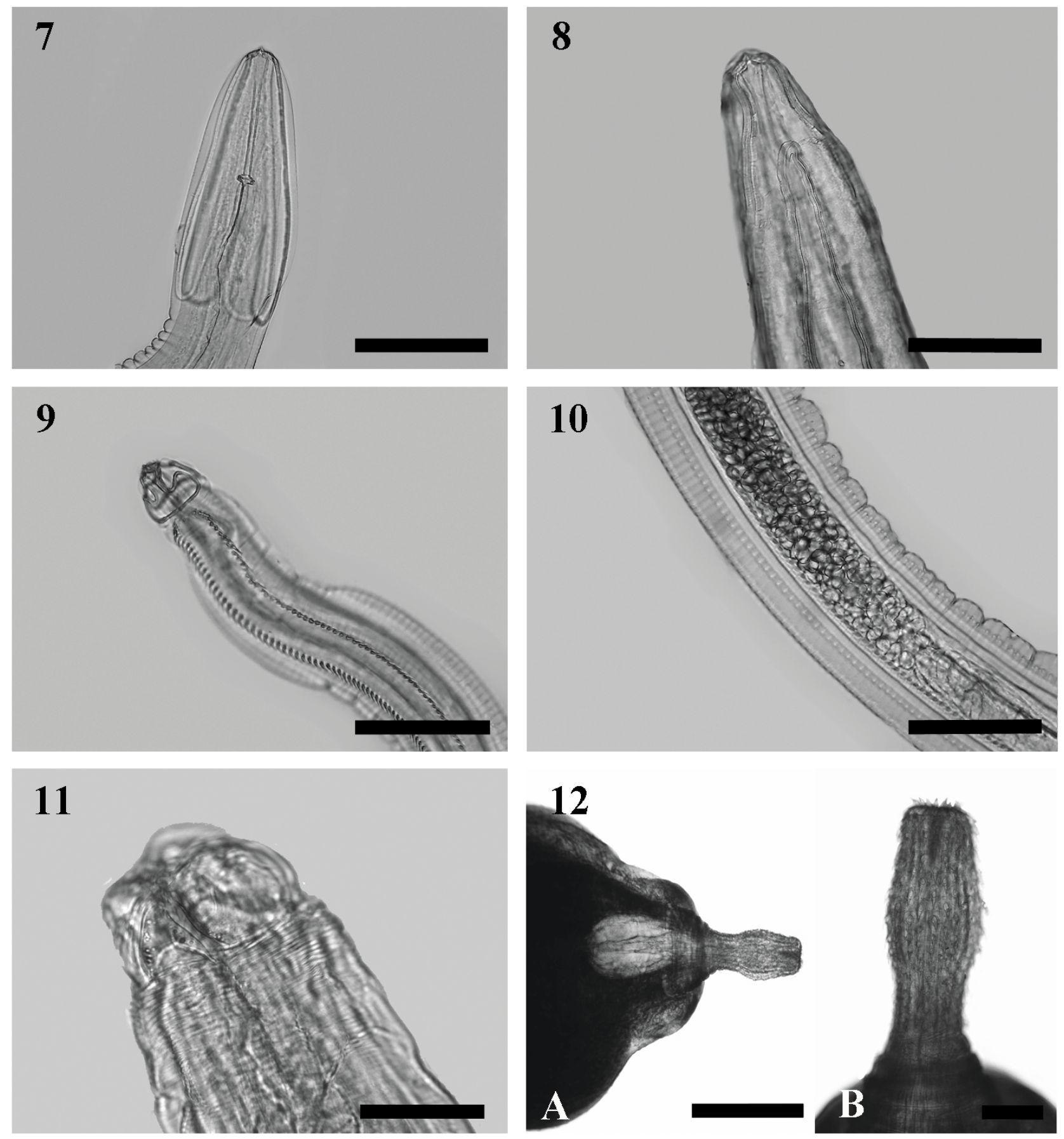

Figs. 7 - 12. Figure 7. Anterior end of Synhimantus (Dispharynx) nasuta. Scale bar $=80 \mu \mathrm{m}$.

Fig. 8. Anterior end of Synhimantus (Synhimantus) sp., with anastomosed cephalic cordons and cuticular plates on the surface of the cordons. Scale bar $=80 \mu \mathrm{m}$. Figs. 9 - 10. Skrjabinoclava sp. 9 . Anterior end and the presence of a double row of spines in each side of the body. Scale bar $=80 \mu \mathrm{m}$. 10. Presence of eggs. Scale bar $=80 \mu \mathrm{m}$. Fig. 11. Anterior end of Contracaecum rudolphii sensu lato. Scale bar $=70 \mu \mathrm{m}$. Fig. 12. Polymorphus mutabilis. A. Broad trunk with proboscis receptable caudal to the small proboscis. Scale bar $=800 \mu \mathrm{m}$. B. Proboscis covered with rows of small hooks. Scale bar $=200 \mu \mathrm{m}$. 
plates along their entire extension. The esophagus is divided into two segments: muscular and a glandular segment, the latter of greater length. The nematode has two bicuspid deirids, one each side. The posterior end of the male has 4 pairs of pre-cloacal papillae and 5 pairs of post-cloacal papillae, also one pair of sessile papillae. Males have one pair of spicules; the left one thinner and with greater length, with the distal third curved on it-self; the rigth one is shorter, stout andanoe-shaped.

\section{Summary}

Site of infection: Gastric lumen

Locality: Valdivia

Prevalence: 1 of $14(7.1 \%)$

Mean intensity: 5.0 (5)

Comments: Only 5 male specimens were isolated. The present parasites are slightly longer than the ones described by Zhang et al. (2004). However the remaining measures and structures as deirids, spicules and pre-cloacal, post-cloacal and sessile papillae were coincident with the description of authors above. Another species isolated from birds of prey is Synhimantus (Dispharynx) mawsonae Zhang \& Beveridge 2007 from Australia (Zhang \& Beveridge, 2007), this species has tricuspid papillae which are located posterior to the cordons, cephalic cordons lacking of plates along their extension, presence of cuticular formations anterior to the cloaca and a shorter left spicule. These characteristics are different from S. (D.) nasuta.

Synhimantus (Dispharynx) nasuta is a nematode that parasites the proventriculus of a wide variety of birds. The life cycle is indirect, with small terrestrial crustaceans as intermediate hosts (Carreno, 2008; Bartmann \& Amato 2009). In raptors has been isolated from esophagus, proventriculus and gizzard of $F$. sparverius, F. tinnunculus and Accipiter trivirgatus formosae Mayr 1949 (Accipitriformes, Accipitridae) from Europe and Asia (Su \& Fei 2004; Acosta et al., 2010). Despite that in the present study no gravid females were detected; this nematode has been isolated from raptors which include arthropods in their diet, which is similarly with M. c. temucoensis (Pavez, 2004), therefore it could be a suitable definitive host. To our knowledge this is the first record in a Neotropical bird of prey.

\section{Genus Synhimantus Railliet, Henry \& Sisoff, 1912 Synhimantus (Dispharynx) sp. (Table 5)}

Description. (Based on 5 whole-mounted mature specimens) The anterior end has a piriform shape. This nematode has 4 non-anastomosed recurrent cephalic cordons, which are corrugated along their entire extension. The cephalic cordons lack of rectangular plates along their entire extension. It also has 2 tricuspid deirids but in some specimens were bicuspid. Posterior end has 4 pairs of pre-cloacal papillae and 5 pairs of post-cloacal papillae, also one pair of sessile papillae. Vulva is located near the middle of the total body length. Males have one pair of spicules of same width; these characteristics and the lack of plates in the cephalic cordons are different from $S$. (D.) nasuta.

\section{Summary}

Site of infection: Crop

Locality: Valdivia

Prevalence: 1 of $14(7.1 \%)$

Mean intensity: 5.0 (5)

Comments: Three gravid females and 2 male worms were isolated. In the gravid females isolated, eggs are distributed within almost the entire body, occupying around two thirds of the total length of the nematode. The spicules of the males in this specimens are longer and wider that $S$. (D.) nasuta, also both spicules have similar width. These parasites were found penetrating the crop mucosa, causing ulcers, and also an evident swelling at the insertion point of the parasite. Similarly Zhang et al. (2004) found male specimens of Synhimantus (Disphaynx) sp. which have both spicules with similar width, however the present specimens differ for morphology and measurements regarding the study above mentioned, although eggs were similar in size. Another raptor infected with Synhimantus (Disphaynx) sp. is E. forficatus (Coulson et al., 2010), however details about the morphology are not given by the author.

\section{Genus Synhimantus Railliet, Henry \& Sisoff, 1912 Synhimantus (Synhimantus) sp. (Fig. 8; Table 5)}

Description. (Based on 4 whole-mounted mature female specimens) Anterior end presents two pair of anastomosed cephalic cordons, which along their entire extension have little rectangular cuticular plates. It also presents a pair of tricuspid deirids, which are caudal to the descending cephalic cordons and nerve ring at the anterior end. There is a clear division between muscular and glandular esophagus, with the latter of greater length. Vulva is located near the middle of the total body length. There is also one pair of phasmids at the posterior end.

\section{Summary \\ Site of infection: Gastric lumen \\ Locality: Valdivia \\ Prevalence: 2 of $14(14.3 \%)$ \\ Mean intensity: $2.0(1-3)$}

Comments: Only 4 female specimens were isolated. Synhimantus (Synhimantus) laticeps Rudolphi 1819 is the type-species for this genus, which has been previously recorded from the gizzard of Tyto alba Scopoli 1769 (Strigiformes, Tytonidae) from Argentina and others raptors from Europe, Asia and Australia (Etchegoin et 


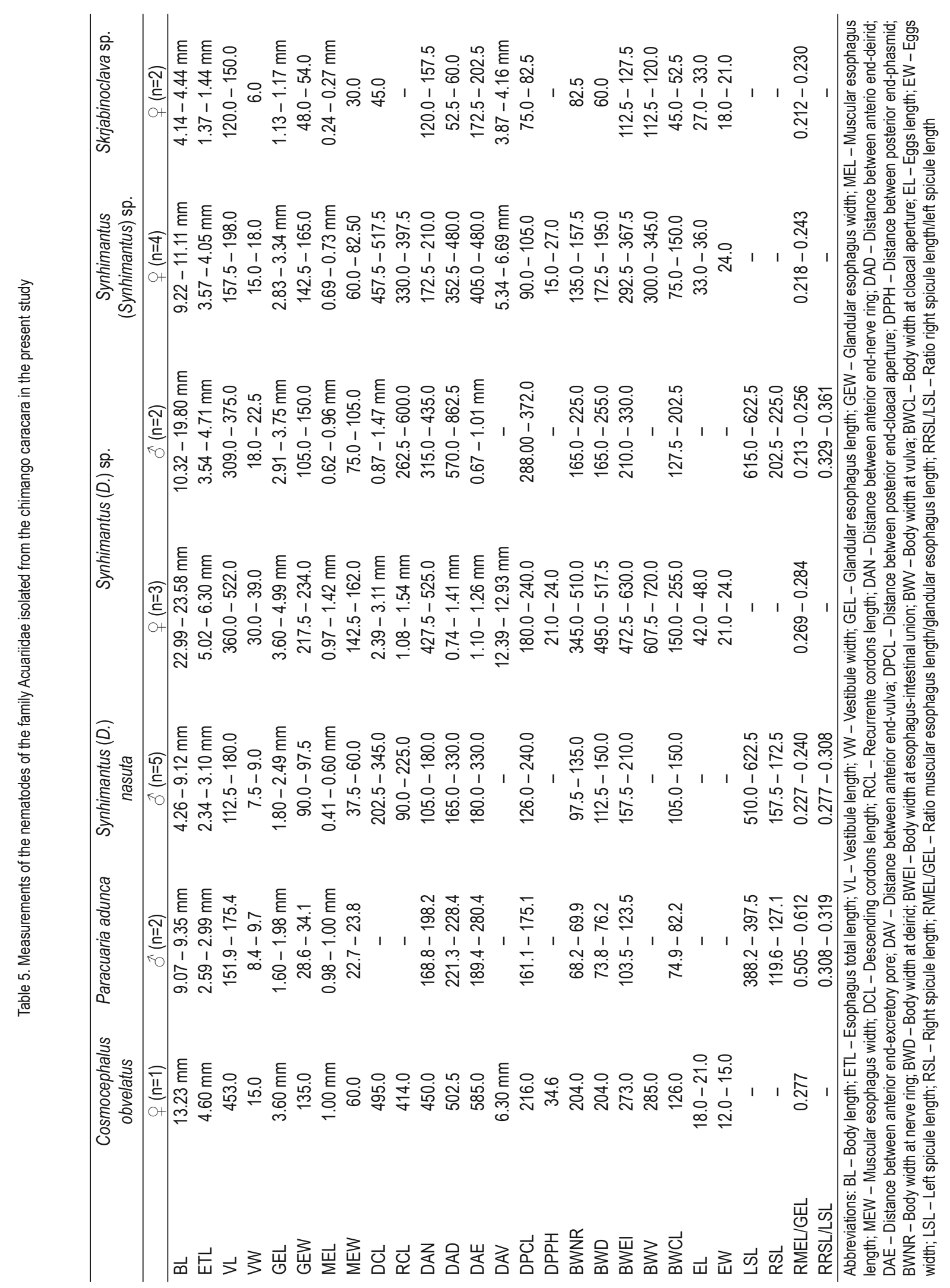


al., 2000; Borgsteede et al. 2003; Zhang \& Beveridge, 2007; Acosta et al., 2010; Umur et al., 2010). Other species have been isolated in raptors; Synhimantus (Synhimantus) rectus (Molin 1860) Gendre 1920 and Synhimantus (Synhimantus) milvagoi Boero \& Led 1971 in the proventriculus and gizzard of several Accipitriformes and Falconiformes from Brazil and Argentina (Boero \& Led, 1971; Magalhães et al., 1994; Vicente et al., 1995; de Melo et al., 2013). The description of S. (S.) milvagoi from Boero \& Led (1971) differs from the present species in several characteristics such as the location of the deirid, being more posterior in $S$. (S.) milvagoi, descending cephalic cordons and recurrent cephalic cordons being shorter, muscular and glandular esophagus shorter, vulva located at the posterior third and eggs a little more slender. Vicente et al. (1995) described S. (S.) rectus, this species has a minor total length, wider body, shorter vestibule length, longer muscular esophagus, shorter glandular esophagus, shorter distance between anterior end and excretory pore, vulva at the posterior third and slender eggs. However without male specimens is difficult achieve the identification of the species.

In the present study, only gravid females were detected and therefore indicating the possibility that chimango caracara could be considered a suitable definitive host, despiting that male specimen were not isolated.

\section{Genus Skrjabinoclava Sobolev, 1943 \\ Skrjabinoclava sp. (Figs. 9 - 10; Table 5)}

Description. (Based on 2 whole-mounted gravid female specimens) Small nematode. The anterior end presents short cephalic cordons, similar in length, which join at the flank of the body with a Greek helmet-like shape. Also has two pairs of rows of spines, one pair each side, that runs from the anterior end almost up to the posterior end. The deirids are located at the beginning of the two rows of spines, one each side, cranial to nerve ring and excretory pore. The vulva is located at the posterior third of body, near the cloaca.

\section{Summary}

Site of infection: Gastric lumen

Locality: Valdivia

Prevalence: 1 of 14 (7.1\%)

Mean intensity: 2.0 (2)

Comments: Only 2 gravid females were found. However the morphological characteristics and measurements were coincident with the female of Skrjabinoclava tupacincai Freitas, Vicente \& Ibañez 1970 described by Wong \& Anderson (1987) in Calidris alba Pallas 1764 (Charadriiformes, Scolopacidae) in Chile. Another species recorded in South America is Skrjabinoclava andersoni Cremonte \& Navone 1999, which was isolated from the proventriculus of $L$. dominicanus and Larus atlanticus Olrog 1858 (Charadrifformes,
Laridae) from Argentina (Cremonte \& Navone, 1999; La Sala et al., 2009), the female of this species is similar to $S$. tupacincai and to the specimens isolated on this study, however the only way to distinguish each other is with the characteristics of the male spicules. The specimens from the present study were bigger that females of Skrjabinoclava spp. found by Acosta et al. (2010) in F. tinnunculus from Spain, but with a lesser distance of deirid from the anterior end, bigger glandular esophagus and smaller muscular esophagus. Skrjabinoclava Sobolev, 1943 has been reported in the proventriculus of aquatic birds. The transmission has not been clarified for any of the species, but is presumed that arthropods act as intermediate hosts. Except for S. tupacincai there is no other records of this species in Chile, thus the chimango caracara probably get infected eating the intermediate host and therefore it is probable that this parasite could be infecting other aquatic birds such as gulls in Argentina. Also the presence of gravid specimens indicate that chimango caracara could be a suitable definitive host, however more studies are required. To our knowledge this is the first record of this species from a Neotropical raptor.

\section{Family Ascarididae Blanchard, 1896 \\ Genus Porrocaecum Railliet \& Henry, 1912 \\ Porrocaecum depressum (Zeder, 1800) Baylis, 1920 (Table 4)}

Description. (Based on 3 whole-mounted mature specimens) Adult nematodes have three lips at the anterior end, which are armed with dentigerous ridges, presence of sharp interlabia is noticeable. There is a cecum, which go to the cranial end, always in close relation to the esophagus, there is also a short ventriculus caudal to the esophagus. In males, both spicules are similar in length, there are also 14 pairs of pre-cloacal papillae and 6 pairs of post-cloacal papillae. On the specimens isolated in this study, both males and females, have a little spine-shaped structure on the tip of the posterior end called mucron, however this structure is absent in larval stages. Posterior end is rounded in both males and females.

\section{Summary}

Site of infection: Gizzard, intestine

Localities: Valdivia, Paillaco

Prevalence: 5 of $14(35.7 \%)$

Mean intensity: $4.0(1-13)$

Comments: Two adult females, 1 adult male and 17 larval worms were isolated. The mucron as itself is not mentioned in the descriptions of this ascarid. However, in the illustrations of Morgan \& Schiller (1950) is evident the presence of the mucron in the posterior end. Such structure was also detected at the posterior end of an adult nematode of Porrocaecum crassum Deslongchamps 1824, from Anas georgica Gmelin 1789 (Anseriformes, Anatidae) (Veterinary Parasitology Laboratory, UACh, unpublished data) in Chile. 
In comparison to Morgan \& Schiller (1950), eggs measurements in the present study were greater to the previously mentioned study, yet other characteristics such as body length, dentigerous ridge in labias, number of pre-cloacal and post-cloacal papillae and similitude of both spicules are coincident for $P$. depressum. Another species isolated from raptors is Porrocaecum angusticolle Molin 1860 (Scott, 1956; Hartwich, 1979), but this species is smaller and spicules are shorter that $P$. depressum. The anatomical sites in the present study were coincident with other studies (Borgsteede et al., 2003; Sanmartín et al., 2004; Su \& Fei, 2004).

Porrocaecum depressum is a common ascarid in birds of prey, for both captive and free-living birds (Krone \& Cooper, 2002). The life cycle is indirect, with earthworms as intermediate hosts and small mammals as paratenic hosts (Fagerholm \& Overstreet, 2008). Both intermediate and paratenic hosts are included in the diet of the chimango caracara (Pavez, 2004).

\section{Family Anisakidae (Railliet \& Henry, 1912) Skryabin \& Karokh- in, 1945}

Genus Contracaecum Railliet \& Henry, 1912

Contracaecum rudolphii (Rudolphi, 1809) Hartwich, 1964 sensu lato

(Fig. 11; Table 4)

Description. (Based on 2 whole-mounted mature specimens) At the anterior end, there are three lips without dentigerous ridges and three bifida interlabias are present. Spicules are similar and very long, reaching approximately half of the body length. Presence of 30 pairs of pre-cloacal papillae and 5 pairs of post-cloacal papillae was also observed. At the first third of the body there is one intestinal cecum directed toward cranial direction and one ventricular appendix directed towards caudal direction. The body is transversally striated. Posterior end is conic.

\section{Summary \\ Site of infection: Gastric lumen \\ Locality: Valdivia \\ Prevalence: 2 of $14(14.3 \%)$ \\ Mean intensity: $12.0(3-21)$}

Comments: Two adult male nematodes and 22 larval nematodes were isolated. The measures and morphological characteristics as number of pre-cloacal and post-cloacal papillae, spicules length, body length and other characteristics are coincident with Amato et al. (2006), although the intestinal cecum and ventricular appendix are shorter. In the case of larvae, the morphological characteristics were coincident with the description of Kanarek \& Bohdanowicz (2009). Recently it was diagnosed a new species from Chile, Contracaecum australe Garbin, Mattiuci, Paoletti, González-Acuña \& Nascetti 2011, which was found in P. brasilianus. This last species has a constriction in the tip of the tail and the presence of a pre-clo- acal median plate, all these characteristics absent in C. rudolphii sensu lato, which is also smaller and thicker. The spicules of $C$. australe are longer in comparison to $C$. rudolphii sensu lato (Garbin et al., 2011).

There are several reports of Contracaecum spp. L3 in fishes from Chile, Argentina and Malvinas (Torres et al., 1991a; Brickle \& MacKenzie, 2007; Alarcos \& Etchegoin, 2010; Carballo et al., 2011; Fernandez et al., 2012). The predation, viscera intake or spreading of these fishes by the fishermen are contributing to the fish-eating birds infection (Torres et al., 1991b). In Chile C. rudolphii s. I., has been identified in Charadriformes, Podicipediformes and Pelecaniformes (Hinojosa-Sáez \& González-Acuña, 2005). Contracaecum spp. has been isolated in Accipitriformes and Falconiformes from Brazil and Taiwan (Magalhães et al., 1994; Su \& Fei, 2004). This is the first report of this species in the chimango caracara. However even when the reproduction in the chimango caracara could not be inferred, this nematode has been isolated from other fish eating raptors (Su \& Fei, 2004). Therefore, it is possible that the present raptor may act as a definitive host.

\section{Phylum Platyhelminthes Gegenbaur, 1859 \\ Family Echinostomatidae Looss, 1899 \\ Genus Stephanoprora Odhner, 1902 Stephanoprora sp.}

Description. (Based on 2 whole-mounted mature specimens) Small trematode; body length $2.91-4.53 \mathrm{~mm}$ (3.72 mm). Slender body and tegument covered with small spines. The anterior end lack of the cephalic spines but there are small depressions where the spines could be inserted. The muscular pharynx is renal-shaped. Oral sucker with terminal location at the anterior end, smaller that cirrus sac and acetabulum. Cirrus sac located caudal to caecal bifurcation and cranial to acetabulum. Uterus located between cirrus sac and anterior testis, with 45-88 operculated eggs. Eggs length 87.42 - 93.21 (90.31), width 58.13 - 62.46 (60.30). Ovary rounded and pre-testicular. Testes tandem, rounded, similar in size to the acetabulum. Vitellaria begin at the posterior end of the anterior testis and reach the posterior end. Ratios FO \% (length forebody/body length) $21.73 \%$, BW \% (body width/body length) $14.60 \%$, T \% (length post-testicular field/body length) $53.31 \%$.

\section{Summary}

Site of infection: Intestine

Locality: Valdivia

Prevalence: 1 of $14(7.1 \%)$

Mean intensity: $2.0(2)$

Comments: Only two ovigerous trematodes were isolated, both with total loss of the cephalic spines. According to Sutton et al. (1982) this loss of spines occurs while the parasites are mounted and stained. In Southamerica several species of Stephanoprora 
Odhner 1902 had been identified: Stephanoprora anomala Travassos 1922, Stephanoprora argentinensis Sutton, Lunaschi \& Topa 1982, Stephanoprora paradenticulata Nasir \& Rodríguez 1969 and Stephanoprora uruguayense Holcman-Spector \& Olagüe 1989 in several orders of fish-eating birds, also Stephanoprora aylacostoma Ostrowski de Núñez \& Quintana 2008 obtained experimentally in Galliformes (Nasir \& Rodríguez, 1969; Sutton et al., 1982; Torres et al., 1983; Torres et al., 1991b; Etchegoin \& Martorelli, 1997; Ostrowski de Núñez et al., 2004; Ostrowski de Núñez, 2007; Ostrowski de Núñez \& Quintana, 2008; Brandao et al., 2013). Regard the morphology and measurements, the present specimens are in agreement with S. uruguayense of Torres et al. (1983) and Ostrowski de Núñez et al. (2004). However because the absence of cephalic spines, structures which according to Kostadinova \& Jones (2005) are of taxonomic importance, the species identification can not be achieved. The life cycle of the genus Stephanoprora is indirect, with aquatic snails as first intermediate host and fishes as second intermediate host (Nasir \& Scorza, 1968). There are previous reports of intermediate hosts in Southamerica, including both snails and fishes (Nasir \& Scorza, 1968; Ostrowski de Núñez, 2007; Ostrowski de Núñez \& Quintana, 2008; Alda \& Martorelli, 2014). To our knowledge there is no previous report of this parasite from a Neotropical raptor.

\section{Phylum Acanthocephala Kohlreuther, 1771 Family Polymorphidae Meyer, 1931 \\ Genus Polymorphus Lühe, 1911}

Polymorphus mutabilis (Rudolphi 1819) Petrochenko 1950 (Fig. 12)

Description. (Based on 4 whole-mounted mature specimens) Female; Body length $6.51-9.04 \mathrm{~mm}(7.77 \mathrm{~mm})$. Proboscis length 735.00 - 772.50 (753.75). Male; Body length $6.03-6.14 \mathrm{~mm}$ (6.08 mm). Proboscis length $615.00-810.00$ (712.50). Anterior end covered with small spines, which correspond to the trunk. The proboscis is cylindrical with hooks of different length, all of them towards cranial direction. In the proboscis, for both males and females, there are 20 rows of hooks with 16 hooks per row in the case of males, and 14 hooks per row in the case of females. Hooks on middle segment of proboscis are longer. The body is globe shaped with two constrictions along its entire extension. Oval eggs with polar prolongations and distributed along the entire body with the exception of the proboscis. Eggs length 120.00, width 33.00 - 36.00 (34.50). Males have one pair of oblique testes and one pair of lemnisci, also presence of Saefftigen's pouch and cement reservoir were observed.

\section{Summary}

Site of infection: Intestine

Locality: Valdivia

Prevalence: 1 of $14(7.1 \%)$

Mean intensity: 4.0 (4)
Comments: Four specimens were isolated. The specimens were found penetrating the intestinal mucosa, causing an ulcerated area at the point of insertion of the proboscis. The morphology, including the number of columns and hooks for each one and also the measurements were agree with Travassos (1926), Schmidt (1965) and Amin (1992). McDonald (1988) isolated Polymorphus miniatus (von Linstow 1896) Travassos 1926, from Anas sp. Linnaeus 1758 (Anseriformes, Anatidae) in Magellan Strait, South America.

Acanthocephalans with aquatic life cycles use crustaceans as intermediate hosts and fishes as paratenic hosts (Richardson \& Nickol, 2008). According to Amin (1992) and Travassos (1926) P. mutabilis has been isolated in South America from Charadriiformes, Pelecaniformes and Coraciiformes. Some common acanthocephala isolated from raptors are Centrorhynchus Lühe 1911, Sphaerirostris Golvan 1956 and Oligacanthorhynchus Travassos 1915 (Richardson \& Nickol, 2008). Other acanthocephalan species isolated from diurnal raptors are Polymorphus brevis Van Cleave 1916 and Polymorphus meyeri Lundström 1942 from Finland and USA (Amin, 1992; Kinsella et al., 1998; Krone et al., 2006). The species detected in the present study has not been recorded previously in Chile. To our knowledge this is the first report in a Neotropical Raptor.

\section{Discussion}

The present study about endoparasites of chimango caracara $M$. chimango corresponds to the second one for Chile, and the first for the southern chimango caracara M. c. temucoensis.

Chimango caracara is a generalist raptor considering its alimentary habits (Pavez, 2004), including crustacean and carrion of fishes as food in Southern Chile (Oyarzún-Ruiz, unpublished data). Similarly, Sazima \& Olmos (2009) recorded this raptor hunting a fish from an estuary. Regarding the isolated parasites; it is important to indicate that $C$. rudolphii sensu lato, $C$. obvelatus, $P$. adunca, Stephanoprora sp. and $P$. mutabilis, require fishes or crustaceans as intermediate or paratenic hosts. The broad diet of chimango caracara, with arthropods, carrion and also the intake of crustaceans and fishes, provide the opportunity to this raptor to acquire new parasitic infections, both terrestrial as aquatic, and complete those life cycles. According to Kinsella et al. (1998) the isolation of gravid specimens would support the possibility of a suitable host. Thus the presence of gravid females in the present survey would indicate the reproduction of these parasites in chimango caracara. Therefore, it is proposed that $M$. chimango would act as definitive host for these parasites previously diagnosed in shorebirds and waterbirds, and would not correspond to accidental records.

In the present study 14 species of helminths were identified, from which there are new records for the chimango caracara in Chile, and also for Neotropical raptors. Capillaria tenuissima, P. spinosa and $P$. depressum were previously reported in this host species. Pterothominx sp., B. falconis, C. obvelatus, Synhimantus (D.) sp., S. (D.) nasuta, Synhimantus (S.) sp., Skrjabinoclava sp., P. adunca, C. rudolphii sensu lato, Stephanoprora sp. and $P$. mutabilis, 
are all new records for $M$. chimango. Meanwhile, for the South American raptors, C. obvelatus, S. (D.) nasuta, Synhimantus (D.) sp., C. rudolphii sensu lato, Skrjabinoclava sp., P. adunca, Stephanoprora sp. and $P$. mutabilis, are first records for that group of birds. Synhimantus (S.) sp. and $P$. adunca correspond to the second and third records, respectively, for South America. In the particular case of Skrjabinoclava sp., the present result is the second worldwide record in a bird of prey, however this is the first time that is proposed that a raptor could be a suitable definitive host.

Considering that most of the present results are new records, additional studies are necessary to analyze the parasitic interaction between this raptor and other birds, as pigeons in the urban area and aquatic birds in the marine and freshwater ecosystems.

\section{Acknowledgment}

We are grateful for the collaboration of the wildlife rescue center Centro de Rehabilitación de Fauna Silvestre (CEREFAS) of the Universidad Austral de Chile, because they provided the specimens that made this work possible. And also to the doctors: Florencia Cremonte, Julia Díaz and Oliver Krone for their help with their publications and scientific advice.

\section{References}

Acosta, I., Hernández, S., Gutiérrez, P., Martínez-Cruz, M., Hernández, E., Buffoni, L., Martínez-Moreno, F. (2010): Acuaroid nematodes in the common kestrel (Falco tinnunculus) in the south of Spain. Vet. J., 183(2): 234 - 237. DOI: 10.1016/j.tvjl.2008.10.013 Alarcos, A., Etchegoin, J. (2010): Parasite assemblages of estuarine-dependent marine fishes from Mar Chiquita coastal lagoon (Buenos Aires Province, Argentina). Parasitol. Res., 107: 1083 1091. DOI: $10.1007 / \mathrm{s} 00436-010-1974-z$

Alda, P., Martorelli, S. (2014): Larval trematodes infecting the South-American intertidal mud snail Heleobia australis (Rissooidea: Cochliopidae). Acta Parasitol., 59(1): 50 - 67. DOI: 10.2478/ s11686-014-0209-3

Amato, J., Monteiro, C., Amato, S. (2006): Contracaecum rudolphii Hartwich (Nematoda, Anisakidae) from the neotropical cormorant, Phalacrocorax brasilianus (Gmelin) (Aves, Phalacrocoracidae) in southern Brazil. Rev. Bras. Zool., 23(4): 1284 - 1289. DOI: 10.1590/S0101-81752006000400046

Amin, O. (1992): Review of the genus Polymorphus Luhe, 1911 (Acanthocephala: Polymorphidae), with the synonymization of Hexaglandula Petrochenko, 1950, and Subcorynosoma Hoklova, 1967, and a key to the species. Qatar Univ. Sci. J., 12: 115 - 123 Anderson, R.C., Wong, P.L. (1982): The transmission and development of Paracuaria adunca (Creplin, 1846) (Nematoda: Acuarioidea) of gulls (Laridae). Can. J. Zool., 60: 3092 - 3104. DOI: 10.1139/z82-393

Ávila, S.D., Bessa, E.C.A., Souza-Lima, S., Rodríguez, M.L.A. (2011): Biased sex ratio and niche restriction in Baruscapillaria ob- signata (Madsen 1945) (Nematoda, Capillariidae) from Columba livia (Aves, Columbidae). J. Helminthol., 86(4): 401 - 405. DOI: 10.1017/S0022149X11000563

Azuma, H., OKamoto, M., Ohbayashi, M., Nishine, Y., Mukal, T. (1988): Cosmocephalus obvelatus (Creplin, 1825) (Nematoda: Acuariidae) collected from the esophagus of Rockhopper penguin, Eudyptes crestatus. Jpn. J. Vet. Res., 36: 73 - 77

Bartmann, A., Amato, S. (2009): Dispharynx nasuta (Nematoda: Acuariidae) em Guira guira e Crotophaga ani (Cuculiformes: Cuculidae) no Estado do Rio Grande do Sul, Brasil. Ciênc. Rural, 39(4): 1152 - 1158. DOI: 10.1590/S0103-84782009005000059

BIRDLIFE INTERNATIONAL (2012): Milvago chimango. In: IUCN 2015. 2015 IUCN The IUCN Red List of Threatened Species. Retrieved July 3, 2015 from http//www.iucnredlist.org

BoERO, J.J., LED, J.E. (1971): El parasitismo de la fauna autóctona. V) Los parasitos de las aves argentinas VI) Los parasitos de los ofidios argentines VII) Los parasites de los murciélagos argentines. Analecta Vet, 3: 91 - 103

Borgsteede, F., Okulewicz, A., Zoun, P., Okulewicz, J. (2003): The helminth fauna of birds of prey (Accipitriformes, Falconiformes and Strigiformes) in the Netherlands. Acta Parasitol., 48(3): 200 - 207

Brandao, M., Luque, J., Scholtz, T., Kostadinova, A. (2013): New records and descriptions of digeneans from the magellanic penguin Spheniscus magellanicus (Forster) (Aves: Sphenisciformes) on the coast of Brazil. Syst. Parasitol., 85: 79 - 98. DOl: 10.1007/ s11230-013-9410-2

Brickle, P., Mackenzie, K. (2007): Parasites as biological tags for Eleginops maclovinus (Teleostei: Eleginopidae) around the Falkland Islands. J. Helminthol., 81: 147 - 153. DOI: 10.1017/ S0022149X07750514

Bush, A., Lafferty, K., Lotz, J., Shostak, A. (1997): Parasitology meets ecology on its own terms: Margolis et al. revisited. J. Parasitol., 83: 575 - 583. DOI: 10.2307/3284227

Carballo, M., Navone, G., Cremonte, F. (2011): Parasites of the silversides Odontesthes smitti and Odontesthes nigricans (Pisces: Atherinopsidae) from Argentinean Patagonia. Comp. Parasitol., 78(1): 95 - 103. DOI: 10.1654/4445.1

CARRENo, R. (2008): Dispharynx, Echinuria and Streptocara. In: ATKInson, C., Thomas, N., Hunter, D. (Eds) Parasitic Diseases of wild birds. lowa, USA: Blackwell Publishing, pp. $326-335$

Coulson, J., TAFT, S., Coulson, T. (2010): Gastrointestinal parasites of the swallow-tailed kite (Elanoides forficatus), including a report of lesions associated with the nematode Dispharynx sp. J. Raptor Res., 44(3): 208 - 214. DOI: 10.3356/JRR-09-71.1

Cremonte, F., Navone, G. (1999): Co-occurrence of Pectinospirura argentata Wehr, 1933, Skrjabinoclava andersoni n. sp. and larvae (Nematoda: Acuariidae) in the proventriculus of Larus dominicanus Lichtenstein (Aves: Laridae), with notes on their attachment. Syst. Parasitol., 42: 203 - 211. DOI: 10.1023/A:1006054720048

De Melo, C., Oliveira, J., Feitosa, T., Vilela, V., Athayde, A., Dantas, A., Wagner, P., Febrônio, A. (2013): Parasites of Psittaciformes and Accipitriformes in Paraíba state, northeastern Brazil. Rev. 
Bras. Parasitol. Vet., 22(2): 314 - 317. DOI: 10.1590/S198429612013000200051

Díaz, J., Cremonte, F., Navone, G. (2001): New host and distribution record of Cosmocephalus obvelatus (Creplin, 1825) (Nematoda: Acuariidae) with morphometric comparitions. Comp. Parasitol., 68(2): $277-282$

Díaz, J., Cremonte, F., Navone, G. (2004): First record of the acuarioid nematode Paracuaria adunca from South America, with new morphological details and discussion of cordons. Comp. Parasitol., 71(2): 238 - 242. DOI: 10.1654/4110

Díaz, J., Cremonte, F., Navone, G. (2010): Helminths of the magellanic penguin, Spheniscus magellanicus (Sphenisciformes), during the breeding season in Patagonian coast, Chubut, Argentina. Comp. Parasitol., 77(2): 172 - 177. DOI: 10.1654/4441.1

Díaz, J., Cremonte, F., Navone, G. (2011): Helminths of the kelp gull, Larus dominicanus, from the northern Patagonian coast. Parasitol. Res., 109: 1555 - 1562. DOI: 10.1007/s00436-011-2396-2

Drago, F.B., LunASCHI, L.I., DraghI, R. (2014): Digenean fauna in raptors from northeastern Argentina, with the description of a new species of Strigea (Digenea: Strigeidae). Zootaxa, 3785(2): 258 270. DOI: $10.11646 /$ zootaxa.3785.2.8

EtChegoin, J., MARToRelli, S. (1997): A new species of the genus Stephanoprora Odhner, 1902 (Digenea, Echinostomatidae) from Argentina. Acta Parasitol., 42(2): 74 - 76

Etchegoin, J., Cremonte, F., Navone, G. (2000): Synhimantus (Synhimantus) laticeps (Rudolphi, 1819) Railliet, Henry et Sisoff, 1912 (Nematoda, Acuariidae) parasitic in Tyto alba (Gmelin) (Aves, Tytonidae) in Argentina. Acta Parasitol., 45(2): 99 - 106

Fagerholm, H.P., Overstreet, R. (2008): Ascaroid Nematodes: Contracaecum, Porrocaecum and Baylisascaris. In: ATKINSON, C., Thomas, N., Hunter, D. (Eds) Parasitic Diseases of wild birds. lowa, USA: Blackwell Publishing, pp. 419

Ferguson-Lees, J., Christie, D. (2006): Systematic section. Raptors of the World. London, England: Christopher Helm Publishers, pp. $317,400-402,518$

Fernandez, V., Semenas, L., Viozzı, G. (2012): Parasites of the "peladilla", Aplochiton zebra (Osmeriformes: Galaxiidae) from Patagonia (Argentina and Chile). Comp. Parasitol., 79(2): 231 - 237. DOI: $10.1654 / 4561.1$

Forbes, N. (2008): Raptors: parasitic disease. In: CHITTY, J., LIERZ, M. (Eds) BSAVA Manual of Rators, Pigeons and Passerine Birds. Gloucester, England: British Small Animal Veterinary Association, pp. $202-211$

FrantovÁ, D. (2002): Some parasitic nematodes (Nematoda) of birds (Aves) in the Czech Republic. Acta Soc. Zool. Bohem., 66(1): $13-28$

Garbin, L., Mattiucci, S., Paoletti, M., González-Acuña, D., Nascet$\mathrm{TI}, \mathrm{G}$. (2011): Genetic and morphological evidences for the existence of a new species of Contracaecum (Nematoda: Anisakidae) parasite of Phalacrocorax brasilianus (Gmelin) from Chile and its genetic relationships with congeners from fish-eating birds. J. Parasitol., 97(3): 476 - 492. DOI: 10.1645/GE-2450.1
González-Acuña, D., Lohse, E., Cicchino, A., Mironov, S., Figueroa, R., Ardiles, K., Kinsella, M. (2011): Parasites of the american kestrel (Falco sparverius) in South-central Chile. J. Raptor Res., 45(2): 188 - 193. DOI: 10.3356/JRR-10-68.1

HARTWICH, G. (1979): Ascariden (Nematoda, Ascaridoidea) aus Vögeln von Ungarn. Parasit. hung., 12: 79 - 85

Hinojosa-SÁez, A., GonzÁlez-Acuña, D. (2005): Estado actual del conocimiento de helmintos en aves silvestres de Chile. Gayana, 69: 241 - 253. DOI: 10.4067/S0717-65382005000200004

Kajerová, V., Baruš, V. (2005): Psittacine birds (Aves: Psittaciformes) as new hosts of Baruscapillaria obsignata (Nematoda: Capillariidae). Acta Vet. Brno, 74: 571 - 574. DOI: 10.2754/ avb200574040571

Kanarek, G., Bohdanowicz, J. (2009): Larval Contracaecum sp. (Nematoda: Anisakidae) in the great cormorant [Phalacrocorax carbo (L., 1758)] from north-eastern Poland: A morphological and morphometric analysis. Vet. Parasitol., 166: 90 - 97. DOI: 10.1016/j.vetpar.2009.08.002

Kellog, F., Prestwood, A. (1968): Case report and differentiating characteristics of Capillaria phasianina from Pen-raised pheasants of Maryland. Avian Dis.: 12(3): 518 - 522. DOI: 10.2307/1588167

Kinsella, J., Foster, G., Cole, R., Forrester, D. (1998): Helminth Parasites of the Bald-Eagle, Haliaeetus leucocephalus, in Florida. J. Helminthol. Soc. Wash., 65: $65-68$

KøIE, M. (1986): The life-history of Mesorchis denticulatus (Rudolphi, 1802) Dietz, 1909 (Trematoda, Echinostomatidae). Z. f. Parasitenkunde., 72: 335 - 343

Kostadinova, A. (2005): Family Echinostomatidae Loos, 1899. In: Jones, A., Bray, R.A., Gibson, D.I. (Eds) Keys to the trematoda. Volume 2. London, UK: CABI Publishing, pp 9 - 64

KRONE, O., CoOPER, J. (1999): Hairworms of birds of prey. Vet. Rec., 145(4): 115

KRONE, O. (2000): Endoparasites in free-ranging birds of prey in Germany. In: LumeiJ, J.t., Remple, D., Redig, P., Lierz, M., Cooper, J. (Eds) Raptor Biomedicine III. Florida, USA: Zoological Education Network, pp. $101-116$

Krone, O., Cooper, J. (2002): Parasitic Diseases. In: Cooper, J. (Ed) Birds of Prey: Health \& Disease. Oxford, UK: Blackwell Publishing, pp. $105-120$

Krone, O., Stuernberg, T., Kenntner, N., Tataruch, F., Koivusaari, J., NuUJA, I. (2006): Mortality factors, helminth burden, and contaminant residues in white-tailed sea eagles (Haliaeetus albicilla) from Finland. Ambio, 35(3): 98 - 104

la Sala, L., Díaz, J., Martorelli, S., Alda, P. (2009): Some nematodes from olrog's gull, Larus atlanticus Olrog, 1958 (Aves: Laridae), and prey crabs from the Bahía Blanca Estuary, Argentina. Comp Parasitol, 76(2): 293 - 296. DOI: 10.1654/4389.1

LuNASCHI, L.I., Drago, F.B. (2009): Digenean parasites of six species of birds from Formosa Province, Argentina. Rev. Mex. Biodivers., 80: $39-46$

Magalhães, R., Vicente, J., Noronha, D. (1994): Nematode parasites of Brazilian accipitrid and falconid birds (Falconiformes). 
Mem. Inst. Oswaldo Cruz, 89(3): 359 - 362. DOI: 10.1590/S007402761994000300010

Mann, A. (1992): Fauna parasitaria en el pingüino de Humboldt (Spheniscus humboldti) en la zona central de Chile. Thesis, Chile, Santiago: Universidad de Chile.

Mawson, P. (1968): Habronematinae (Nematoda: Spiruridae) from Australian birds. Parasitology, 58: 745 - 767. DOI: 10.1017/ S0031182000069559

McDonald, E. (1988): Family Polimorphidae: Genus Polymorphus. Key to Acanthocephala Reported in Waterfowl. Washington D.C., USA: Fish and Wildlife Service, pp. 26 - 38

MetTRICK, D. (1959): On the nematode genus Capillaria in british birds. Ann. Mag. Nat. Hist., 2(14): 65 - 84. DOI: 10.1080/00222935908651029

Morgan, B., Schiller, E. (1950): A note on Porrocaecum depressum (Zeder, 1800) (Nematoda: Anisakinae). Trans. Am. Microsc. Soc., 69: 210 - 213. DOI: 10.2307/3223411

Mutafchiev, Y., Halajian, A., Georgiev, B. (2010): Two new nematode species of the genus Cosmocephalus Molin, 1858 (Spirurida: Acuariidae), with an amended generic diagnosis and an identification key to Cosmocephalus spp. Zootaxa, 2349: 1 - 20. DOI: $10.11646 / \% 25 x$

NASIR, P., ScoRZA, J. (1968): Studies on Freshwater Larval Trematodes XVIII. The life cycle of Stephanoprora denticulata (Rudolphi, 1802) Odhner, 1910 (Trematoda: Digenea: Echinostomatidae). Z. f. Parasitenkunde 30: 134 - 148

NAsIR, P., RodRíguez, L. (1969): Studies on freshwater larval trematodes. XX. The life cycle of Stephanoprora paradenticulata $\mathrm{n} . \mathrm{sp}$. (Trematoda, Echinostomatidae). Zool. Anz., 182: 230 - 244

Ostrowski De Núñez, M., Flores, V., Viozzı, G., Kreiter, A. (2004): Stephanoprora uruguayense Holcman-Spector et Olagüe, 1989 (Digenea, Echinostomatidae) from Argentina, and comments on species of Stephanoprora from birds of the Neotropical Region. Acta Parasitol., 49(4): 1230 - 2821

Ostrowskı De NúNEEz, M. (2007): Life cycle of Stephanoprora uruguayense (Digenea: Echinostomatidae) in Argentina. J. Parasitol., 93(5): 1090 - 1096. DOI: 10.1645/GE1176R.1

Ostrowskı De NúÑEz, M., Quitana, M. (2008): The life cycle of Stephanoprora aylacostoma n. sp. (Digenea: Echinostomatidae), parasite of the threatened snail Aylacostoma chloroticum (Prosobranchia, Thiaridae), in Argentina. Parasitol. Res., 102: 647 - 655. DOI: 10.1007/s00436-007-0806-2

Pavez, E. (2004): Descripción de las aves rapaces chilenas. In: Muñoz, A., Rau, J., YÁñez, J. (Eds) Aves Rapaces de Chile. Valdivia, Chile: CEA Ediciones, pp. 29 - 77

Pazmiño, A. (2007): Estudio de la fauna parasitaria intestinal en palomas (Columba livia Gmelin, 1789) de la ciudad de Valdivia. Thesis, Chile, Valdivia: Universidad Austral de Chile

Pinto, R.M., NoronhA, D. (2003): Analysis of Brazilian species of Pelecitus Railliet \& Henry (Nematoda, Filarioidea) with the establishment of new records. Rev. Bras. Zool., 20(2): 361 - 364. DOI: 10.1590/S0101-81752003000200029
Raimilla, V., Rau, J., Muñoz-Pedreros, A. (2012): Estado de arte del conocimiento de las aves rapaces de Chile: Situación actual y proyecciones futuras. Rev. Chil. Hist. Nat., 85: 469 - 480. DOI: 10.4067/S0716-078X2012000400009

RAO, N. (1951): Paracuaria macdonaldi n.g. n. sp. (Family Acuariidae, Subfamily Acuariinae) from the sea gull (Larus argentatus). Can. J. Zool., 29: 167 - 172. DOI: 10.1139/z51-015

READ, C. (1949): Studies on north American helminthes of the genus Capillaria Zeder, 1800 (Nematoda): III. Capillarids from the Lower Digestive Tract of North American Birds. J. Parasitol., 35(3): $240-249$

Richardson, D., Nickol, B. (2008): Acanthocephala. In: AtKInson, C., Thomas, N., Hunter, D. (Eds) Parasitic Diseases of wild birds. lowa, USA: Blackwell Publishing, pp. 277 - 283

Rodrigues, H.O. (1996): Espécies de Thelaziinae (Skrjabin) Baylis \& Daubney (Nematoda, Thelazioidea) referidas para 0 Brasil. Rev. Bras. Zool., 13(2): 343 - 350. DOI: 10.1590/S010181751996000200006

Ruff, M., Norton, R. (1997): Parásitos internos nematodes y acantocéfalos. In: COLNEK, B. (Ed) Enfermedades de las aves. España: Editorial Manual Moderno, pp. 854

San Martín, J., Brevis, C., Rubilar, L., Krone, O., González-Acuña, D. (2006): Parasitismo gastrointestinal en tiuque común Milvago chimango chimango (Vieillot, 1816) (Falconidae, Aves) en Ñuble, Chile. Parasitol. Latinoam., 61: 63 - 68. DOI: 10.4067/S071777122006000100009

SAn Martín-ÓRdenes, J. (2011): Diversidad de Trichinelloidea (Enoplea, Nematoda) en Chile y su implicancia en salud humana, animal y ecosistémica. Lundiana, 10: 19 - 52

Sanmartín, L., Álvarez, F., Barreiro, G., Leiro, J. (2004): Helminth fauna of Falconiform and Strigiform birds of prey in Galicia, Northwest Spain. Parasitol. Res., 92: 255 - 263. DOI: 10.1007/s00436003-1042-z

Sazima, I., Olmos, F. (2009): The Chimango Caracara (Milvago chimango), an additional fisher among Caracarini falcons. Biota Neotrop., 9: $403-405$

SCHMIDT, G. (1965): Polymorphus swartzi sp. n., and other Acanthocephala of Alaskan ducks. J. Parasitol., 51(5): 809 - 813. DOI: 10.2307/3276165

ScotT, D.M. (1956): On the specific identity of the larval Porrocaecum (Nematoda) in Atlantic cod. J. Fish. Res. Board Can., 13(3): 343 - 356. DOI: $10.1139 / \mp 56-023$

Su, Y., FEl, A. (2004): Endoparasites of the Crested Goshawk, Accipiter trivirgatus formosae, from Taiwan, Republic of China. Comp. Parasitol., 71: 178 - 183. DOI: 10.1654/4107

Sutton, C., LunASCHI, L., TopA, P. (1982): Fauna helmintologica de la saves del lago Pellegrini. I. Trematoda-Echinostomatidae en Podiceps major (Boddaert), Rollandia Rolland (Quoy \& Gaymard) y Bubulcus ibis (Linne). Limnobios, 2(5): 336 - 341

Torres, P., Figueroa, L., Saldivia, A. (1983): Stephanoprora denticulata (Trematoda, Echinostomatidae) en gaviotas del sur de Chile. Bol. Chil. Parasitol., 38: $33-34$ 
Torres, P., Cabezas, X., Arenas, J., Miranda, J., Jara, C., Gallardo, C. (1991a): Ecological aspects of nematode parasites of introduced salmonids from Valdivia river basin, Chile. Mem. Inst. Oswaldo Cruz, 86(1): 115 - 122. DOI: 10.1590/S0074-02761991000100018 Torres, P., Ruiz, E., Gesche, W., Montefusco, A. (1991b): Gastrointestinal helminths of fish-eating birds from Chiloe Island, Chile. J. Wildl. Dis., 27: 178 - 179. DOI: 10.7589/0090-3558-27.1.178 Travassos, L. (1926): Contribuicoes para o conhecimento da fauna helminthological brasileira. XX Revisao dos Acanthocephalos brasileiros. Parte II. Familia Echinorhynchidae Hamann, 1892, sub-fam. Centrorhynchinae Travassos, 1919. Mem. Inst. Oswaldo Cruz, 19(1): 31 - 125. DOI: 10.1590/S0074-02761926000100003 Travassos, L., Teixeira De Freitas, J.F., Kohn, A. (1969): Trematódeos do Brasil. Mem. Inst. Oswaldo Cruz, 67: 1 - 886.

Umur, S., Beyhan, Y.E., Pekmezcí, G.Z., Acicl, M., Gürler, A.T. (2010): First record of Synhimantus (S.) laticeps (Rudolphi, 1819) Railliet, Henry et Sisoff, 1912 (Nematoda, Acuariidae) in Accipiter nisus (Aves, Accipitridae) in Turkey. Ankara Üniv. Vet. Fak., 57: $139-142$

Vicente, J.J., Rodriguez, H.O., Gomes, D.C., Pinto, R.M. (1995): Nematóides do Brasil. Parte IV: Nematóides de aves. Rev. Bras. Zool., 12: 1 - 273. DOI: 10.1590/S0101-81751995000500001

Wobeser, G. (2008): Parasitism: Costs and Effects. In: AtKInson, C., Thomas, N., Hunter, D. (Eds) Parasitic Diseases of wild birds. lowa, USA: Blackwell Publishing, pp. 3 - 8
Wong, P.L., Anderson, R.C. (1987): New and described species of Skrjabinoclava Sobolev, 1943 (Nematoda: Acuarioidea) of the proventriculus of nearctic waders (Aves: Charadrifformes) with a review of the genus and a key to species. Can. J. Zool., 65: 2760 - 2779. DOI: 10.1139/z87-418

Wong, P.L., Anderson, R.C. (1982a): The transmission and development of Cosmocephalus obvelatus (Nematoda: Acuarioidea) of gulls (Laridae). Can. J. Zool., 60: 1426 - 1440. DOI: 10.1139/z82-192

Wong, P.L., Anderson, R.C. (1982b): Redescription of Paracuaria adunca (Creplin, 1846) (Nematoda: Acuarioidea) from Larus delawarensis Ord (Laridae). Can. J. Zool., 60: 1426 - 1440. DOI: 10.1139/Z82-023

YabSLEY, M. (2008): Capillarid Nematodes. In: Atkinson, C., ThomAs, N., Hunter, D. (Eds) Parasitic Diseases of wild birds. lowa, USA: Blackwell Publishing, pp. 463 - 489

Zhang, L., Brooks, D., Causey, D. (2004): Two species of Synhimantus (Dispharynx) Railliet, Henry and Sisoff, 1912 (Nematoda: Acuarioidea: Acuariidae), in passerine birds from the Área de Conservación Guanacaste, Costa Rica. J. Parasitol., 90(5): 1133 $-1138$

Zhang, L., Beveridge, I. (2007): Description of Synhimantus (Dispharynx) mawsonae n. sp. and a redescription of Procyrnea dollfusi (Mawson, 1968) (Nematoda: Spirurida) from the southern boobook owl, Ninox boobook (Latham, 1802) (Aves: Strigidae). Trans. R. Soc. S. Aust., 132(2): $152-159$ 